Macmillan History of Europe

Eighteenth-Century Europe 


\section{HISTORY OF EUROPE}

\section{PUBLISHED}

Early Medieval Europe, 300-1000 (second edition)

Roger Collins

Sixteenth-Century Europe

Richard Mackenney

Seventeenth-Century Europe, 1598-1700

Thomas Munck

Eighteenth-Century Europe (second edition)

Jeremy Black

\section{FORTHCOMING}

Nineteenth-Century Europe, 1789-1914

Alan Sked

Twentieth-Century Europe

Richard Vinen

History of Europe

\section{Series Standing Order}

ISBN 978-0-333-71699-1 hardcover

ISBN 978-0-333-69381-0 paperback

(outside North America only)

You can receive future titles in this series as they are published by placing a standing order. Please contact your bookseller or, in the case of difficulty, write to us at the address below with your name and address, the title of the series and the ISBN quoted above.

Customer Services Department, Macmillan Distribution Ltd Houndmills, Basingstoke, Hampshire RG21 6XS, England 
Macmillan History of Europe

\section{Eighteenth-Century Europe}

Jeremy Black

Second Edition

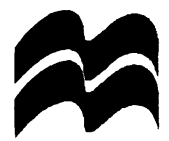




\section{m}

(C) Jeremy Black 1990, 1999

All rights reserved. No reproduction, copy or transmission of this publication may be made without written permission.

No paragraph of this publication may be reproduced, copied or transmitted save with written permission or in accordance with the provisions of the Copyright, Designs and Patents Act 1988, or under the terms of any licence permitting limited copying issued by the Copyright Licensing Agency, 90 Tottenham Court Road, London W1P 9HE.

Any person who does any unauthorised act in relation to this publication may be liable to criminal prosecution and civil claims for damages.

The author has asserted his right to be identified as the author of this work in accordance with the Copyright, Designs and Patents Act 1988.

First edition 1990

Second edition 1999

MACMILLAN PRESS LTD

Houndmills, Basingstoke, Hampshire RG21 6XS

and London

Companies and representatives

throughout the world

ISBN 978-0-333-77335-2

ISBN 978-1-349-27768-1 (eBook)

DOI 10.1007/978-1-349-27768-1

A catalogue record for this book is available from the British Library.

This book is printed on paper suitable for recycling and made from fully managed and sustained forest sources.

$\begin{array}{llllllllll}10 & 9 & 8 & 7 & 6 & 5 & 4 & 3 & 2 & 1\end{array}$

$\begin{array}{llllllllll}08 & 07 & 06 & 05 & 04 & 03 & 02 & 01 & 00 & 99\end{array}$

Published in the United States of America by

ST. MARTIN'S PRESS, INC.,

Scholarly and Reference Division

175 Fifth Avenue, New York, N.Y. 10010

ISBN 978-0-312-22539-1 (paper) 


\section{To Robert Baldock}

a friend whose wise counsel

I appreciate as greatly as

I enjoy his company 


\section{Contents}

List of maps

Chronology

$x$
$x i$
$x v$
$x v i i i$

Preface to the second edition

1 Hostile Environment

Demography, disease and death

Calamities and conservatism

2 Economic Framework $\quad 26$

Agriculture $\quad 26$

$\begin{array}{ll}\text { Industry } & 48\end{array}$

3 The Wheels of Commerce $\quad 64$

Communications 64

Money, standards and credit $\quad 70$

$\begin{array}{ll}\text { Trade } & 78\end{array}$

A changing economy $\quad 95$

4 Society 102

$\begin{array}{ll}\text { Women and families } & 102\end{array}$

The orders of society 118

Nobility $\quad 125$

The middling orders $\quad 142$

Peasantry 143

5 Towns $\quad 164$

Growth or decline $\quad 165$

Towns as centres of privilege and control $\quad 170$

Town and country $\quad 175$

$\begin{array}{ll}\text { Towns and social hierarchy } & 182\end{array}$

$\begin{array}{ll}\text { Towns and political strife } & 188\end{array}$ 
The urban environment $\quad 190$

Poverty and social welfare 192

6 Faith and the Churches 200

A divided continent 201

Growth of toleration $\quad 215$

De-christianisation? $\quad 218$

Jansenism 226

The fate of the Jesuits 230

Church-State relations 233

The Christian mission and the churches 242

\section{Enlightenment}

8 Culture and the Arts 263

Patronage 263

Courts and aristocracies $\quad 264$

Religion and the Church $\quad 272$

The middling orders: patronage by the public market

276

The populace: distinct and oppressed? $\quad 282$

Changing styles 286

Cosmopolitanism and artistic influences 292

Language 298

9 Science and Medicine $\quad 306$

10 International Relations 323

An overview 323

European diplomacy 1700-21 326

European diplomacy 1721-40 335

European diplomacy 1740-63 338

European diplomacy 1763-93 343

Conclusion 351

11 Armies and Warfare 353

Russia $\quad 354$

Mid-century Prussia 357

Mid-century reform in Austria and Russia $\quad 359$

After the Seven Years War 362

Reform in the French army 363

Continuing problems $\quad 364$

Recruitment $\quad 365$ 
Warfare and the militarised society 371

Naval warfare

Conclusion

12 Europe and the Outer World

Europe and the non-European World

Exploration

391

The colonial struggle

393

European colonies

402

Slavery

405

Conclusion

13 Government and Administration

Public order, crime and law

412

Fiscal problems

Regions on the margins of authority

Government agencies

Winning consent: the process of government

Enlightened Despotism

14 Ideology, Politics and Reform

Political thought

Politics

15 The Revolutionary Crisis

The coming of revolution

Crisis in France

The summer of 1789

The October Days to Varennes, 1789-91:

From Varennes to War, 1791-2

From the Republic to the Terror, 1792-4

From Thermidor to Napoleon: The failure of the Liberal Republic, 1794-9

Conclusion

Notes 


\section{List of Maps}

1 Europe 1700

$\mathrm{xx}$

2 The Habsburg Empire

xxii

3 Italy $1713-48$

xxiv

4 France in 1789

XXV 


\section{Chronology}

\section{International relations}

1698, 1700 First and Second Partition Treaties divide Spanish empire between claimants

1700 Outbreak of Great Northern War. Charles II of Spain dies

1701 Hostilities begin in War of the Spanish Succession. England enters war in 1702

$1704 \quad$ Battle of Blenheim

$1709 \quad$ Battle of Poltava

1711 Pruth campaign

1713 Peace of Utrecht end War of the

1714 Peace of Rastadt Spanish Succession

1716-18 Austro-Turkish War

1717

1718 Spain conquers Sardinia

Spain attacks Sicily. Start of conflict between Spain, and Britain and France (ends 1720)

1721 Treaty of Nystad: end of Great Northern War

1725 Treaties of Vienna (Austria, Spain) and Hanover (Britain, France, Prussia)

1731 Second Treaty of Vienna: Anglo-Austrian alliance

1733-5 War of the Polish Succession

1735 Outbreak of Russo-Turkish hostilities

1737 Austria joins Russia

1739 Treaty of Belgrade: end of Balkan war

1739-48 Anglo-Spanish conflict: War of Jenkins' Ear

1740 Prussia invades Silesia: start of War of the Austrian Succession

1741-3 Russo-Swedish War

1748 Treaty of Aix-la-Chapelle ends War of the Austrian Succession

1754

Anglo-French hostilities begin in North America

1755 Outbreak of undeclared Anglo-French war: formal hostilities in 1756

1756 Anglo-Prussian Treaty of Westminster. Austro-French Treaty of Versailles. Frederick II invades Saxony. Outbreak of Seven Years War 
1759

1761

1763

1768

1772

1774

1776

1778-9

1778

1781

1783

1786

1787

1788

1790

1791

1792

1793

1795

\section{Britain}

1701

1707

1714

1715-16

1716

1720

1721

1733

1742

1745-6

1754

Britain's year of victories. Fall of Québec

Third Family Compact: France-Spain. First two in 1733 and 1743

Peace of Paris and Treaty of Hubertusburg end Seven Years War

Outbreak of Russo-Turkish war. France purchases Corsica

First partition of Poland

Treaty of Kutchuk-Kainardji: ends Russo-Turkish war

American Declaration of Independence

War of Bavarian Succession

France enters War of American Independence

Austro-Russian alliance against Ottoman Empire

Russia seizes Crimea. Treaty of Versailles ends American war

Anglo-French commercial treaty

Turks attack Russia. Prussians intervene in the United Provinces

Gustavus III of Sweden attacks Russia

End of Austro-Turkish and Russo-Swedish hostilities.

Anglo-Spanish Nootka Sound Crisis

Ochakov Crisis between Britain and Russia

Treaty of Jassy ends Russo-Turkish conflict.

Outbreak of the French Revolutionary war

Britain joins Revolutionary war. Second Partition of Poland

Third Partition of Poland

Act of Settlement establishes terms of Hanoverian succession

Union of England and Scotland

Whigs replace Tories following accession of George I

Jacobite rising

Septennial Act: elections only necessary every 7 years

South Sea Bubble bursts

Walpole becomes chief minister

Excise Crisis

Walpole falls after 1741 elections

Jacobite rising

Death of Henry Pelham inaugurates period of ministerial instability 
1757-61 Pitt-Newcastle ministry

1770-82 Lord North chief minister

1781

1783

Surrender of army at Yorktown

$1788-9$

William Pitt the Younger becomes chief minister

Regency crisis

\section{France}

1713

1715

1720

Bull Unigenitus condemns alleged Jansenist doctrines Accession of Louis XV. Orléans regent until 1723

$1726-43$ Collapse of Law's financial schemes

1749

Cardinal Fleury chief minister

1751

New tax, the Vingtième, imposed

$1758-70$

First volume of Encyclopédie appears

1764

Duc de Choiseul chief minister

1771

Expulsion of the Jesuits

1774

1774-6

1787

The 'Maupeou Revolution': reorganisation of the parlements

Accession of Louis XVI, fall of Maupeou, recall of parlements

Turgot controller-general of finances

Assembly of Notables meets. Calonne replaced by Brienne

1788 Assembly of Notables fails. Estates General summoned. Brienne replaced by Necker

$1789 \quad$ Estates General meets. Fall of the Bastille. Estates General becomes National Assembly. Declaration of the Rights of Man and the Citizen

1791 Flight to Varennes. New constitution

$1792 \quad$ Monarchy abolished

$1793 \quad$ Louis XVI executed

\section{Habsburg Territories}

1703-11 Rakoczi rising in Hungary

1711 Hungary revolt ended by Peace of Szatmár

1713 Pragmatic Sanction issued

1753-93 Kaunitz chancellor

1781 Religious liberty granted to non-Catholic Christians

1782 Pius VI visits Vienna 


\section{Prussia}

1722

1740

1744

1766

\section{Russia}

1700

1703

1708

1710-11

1711

1718

1722

1730

1741

1762

1767

$1773-5$

1775

1785
General Directory established

Frederick II accedes and invades Silesia

Acquisition of East Friesland

New excise introduced

\section{Other States}

1720 New written constitution greatly reduces power of

Swedish monarchy

1747 Orangist revolution in the United Provinces

1750-77 Pombal chief minister in Portugal

1759 Jesuits expelled from Portugal

1759-76 Tanucci chief minister in Naples

1765-90 Grand Duke Leopold ruler of Tuscany

1770-2 Struensee reforms in Denmark

1773 Dissolution of the Jesuit Order

$1786 \quad$ Synod at Pistoia 


\section{Rulers of the Major States}

Austrian Dominions: Habsburgs

Leopold I

1657-1705

Joseph I

1705-1711

Charles VI

$1711-1740$

Maria Theresa

$1740-1780$

(Joseph II co-regent

1765-1780)

Joseph II

$1780-1790$

Leopold II

1790-1792

France: Bourbon dynasty

Louis XIV

1643-1715

Louis XV

1715-1774

(Regency of duke of Orléans

Louis XVI

1715-1723)

1774-1793

\section{Great Britain}

William III

1689-1702

Anne

1702-1714

George I

George II

George III

1714-1727

1727-1760 Hanoverian

1760-1820 $\}$ dynasty

\section{Prussia: Hohenzollerns}

Frederick I

Frederick William I

Frederick II 'the Great'

Frederick William II
1688-1713

1713-1740

1740-1786

1786-1797 
xvi Rulers of the major states

Russia: Romanovs

Peter I 'the Great'

$1682-1725$

Catherine I

$1725-1727$

Peter II

1727-1730

Anna

$1730-1740$

Ivan VI

1740-1741

Elizabeth

1741-1762

Peter III

1762

Catherine II 'the Great'

1762-1796

\section{Spain: Bourbons}

Philip V

Ferdinand VI

Charles III

Charles IV
$1700-1746$

1746-1759

$1759-1788$

1788-1808

\section{Sweden: Vasa}

Charles XII

1697-1718

Ulrika Eleonora

$1718-1720$

Frederick I

$1720-1751$

Adolphus-Frederick

$1751-1771$

Gustavus III

$1771-1792$

\section{United Provinces (Dutch Republic): stadtholders}

William III

No stadtholders in major provinces

William IV

William V
1672-1702

$1702-1747$

$1747-1751$

1751-1795

\section{Popes}

$\begin{array}{ll}\text { Innocent XII } & 1691-1700 \\ \text { Clement XI } & 1700-1721 \\ \text { Innocent XIII } & 1721-1724 \\ \text { Benedict XIII } & 1724-1730 \\ \text { Clement XII } & 1730-1740\end{array}$


Rulers of the major states $\mathrm{xvii}$

Benedict XIV

$1740-1758$

Clement XIII

$1758-1769$

Clement XIV

$1769-1774$

Pius VI

$1775-1799$

Pius VII

$1800-1823$

Frederick II of Prussia is referred to in the text as Frederick the Great to distinguish him from Frederick II of Hesse-Cassel. 


\section{Preface to the Second Edition}

'Not enough on Rousseau. Too much on Russia.' 'Too much on Russia. Not enough on Rousseau.' If it is impossible to write a general work that will satisfy all, that has become even more the case as the scholarly agenda has widened. It is no longer acceptable to offer simply what one scholar unfairly reviewing an earlier general work on this period referred to as "comfortable old chums like "The Rise of Great Britain", "The Decline of the Dutch Republic" and "The Emergence of Prussia". The selection of material entails the risk of bias. How is the teleological challenge posed by the French and industrial revolutions to be faced? Is what happened in Prussia more important than developments in Piedmont? As there are no obvious criteria by which such questions can be answered those interested in this period can benefit from the varied approaches of different scholars. This book is thematic rather than chronological or national in its organisation. For those who prefer the latter approaches there are a number of excellent surveys available.

I owe thanks to a number of institutions and individuals. By asking me to produce an expanded edition of this book Jonathan Reeve provided me with the opportunity of undertaking a very interesting project. Two chapters are entirely new and all the others have been extensively revised. My research was helped by those institutions which, in supporting foreign archival work, gave me the opportunity to work in libraries after the archives were shut. Furthermore, the book benefits from my work in Austrian, British, Dutch, French, German and Italian archives since 1978. The use of original examples enlivens this study and, more significantly, a grounding in eighteenth-century archival sources has provided a grasp of the uncertainties and compromises of the period. This contributes to a feature of this book, an emphasis on the difficulty of offering sweeping explanations. Instead, there is a stress on the contrasts of the age, the variety of developments and the complexity of analysis. In place of traditional preconceptions and easy explanatory antitheses, such as despotism and revolution, ancien régime and new order, privilege and protest, tradition and progress, stability and strife, liberty and order, 
authoritarianism and affection, high and low culture, there is a concern with detail in order both to show the vivid concreteness of the age and to suggest interaction as well as tensions within the eighteenth-century world. There is also a stress on the protean, adaptable character of the old order.

Wendy Duery provided crucial secretarial support. Matthew Anderson, Nigel Aston, Edward Corp, Malcolm Crook, Bill Gibson, Sheridan Gilley, Jan Glete, Nick Henshall, Murray Pittock, David Sturdy and Peter Wilson helpfully discussed aspects of the new edition, which was written in the summer of 1998 . The preface to the last edition closed: 'The book was begun in 1983, two homes ago. I thank Sarah for everything.' Now, it should read three homes. The thanks are the same.

JEREMY BLACK 


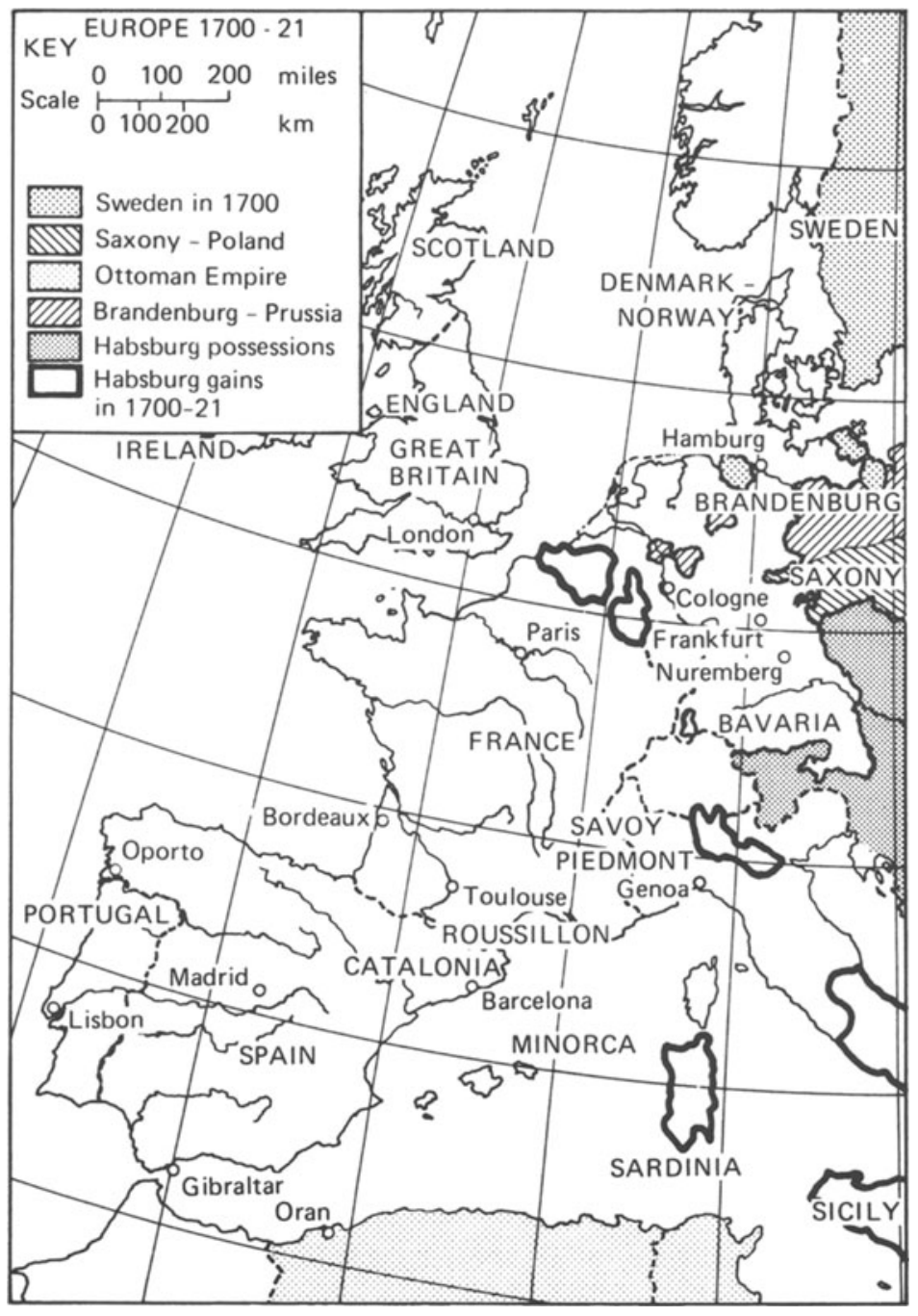

Map 1 Europe 1700 


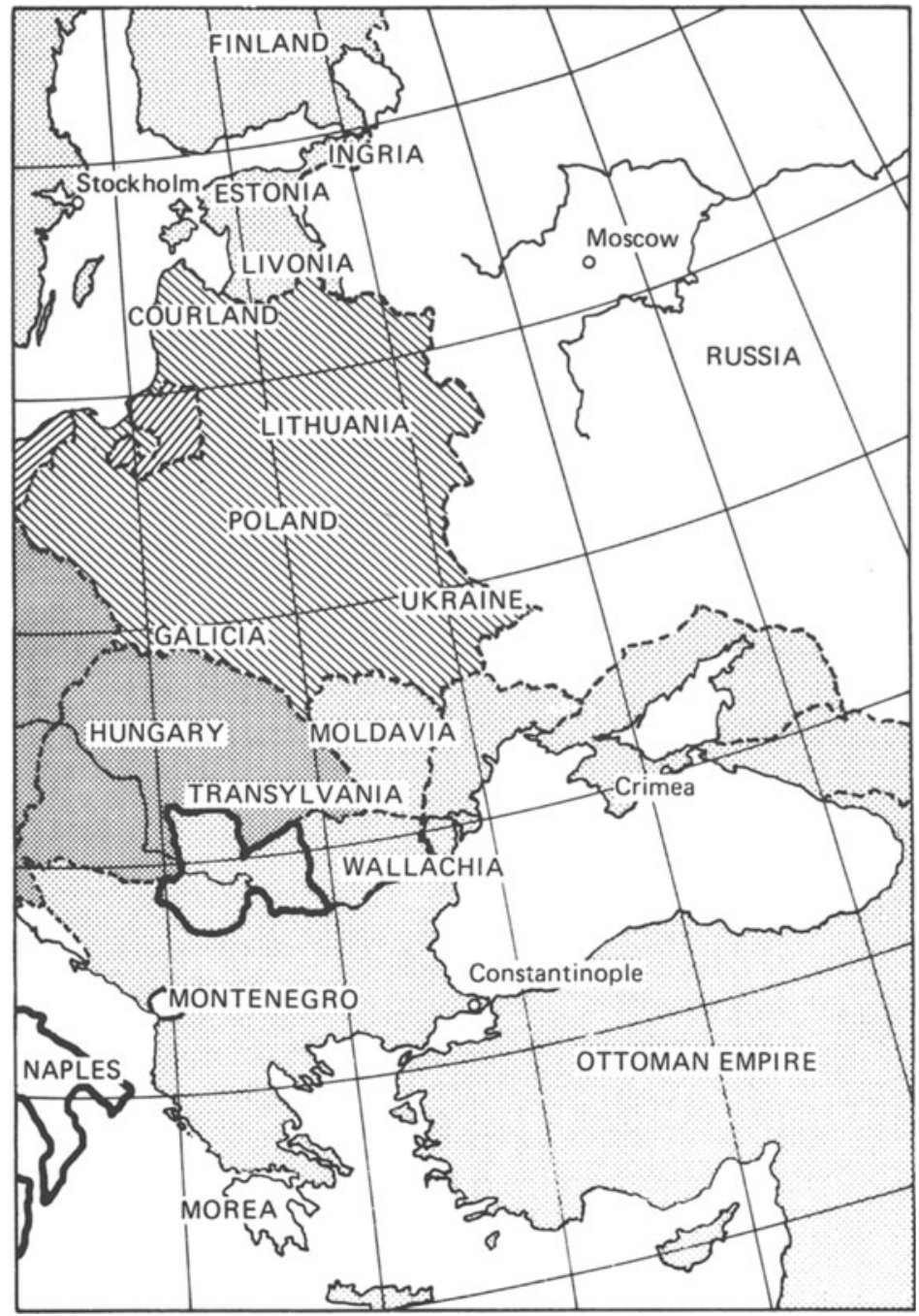




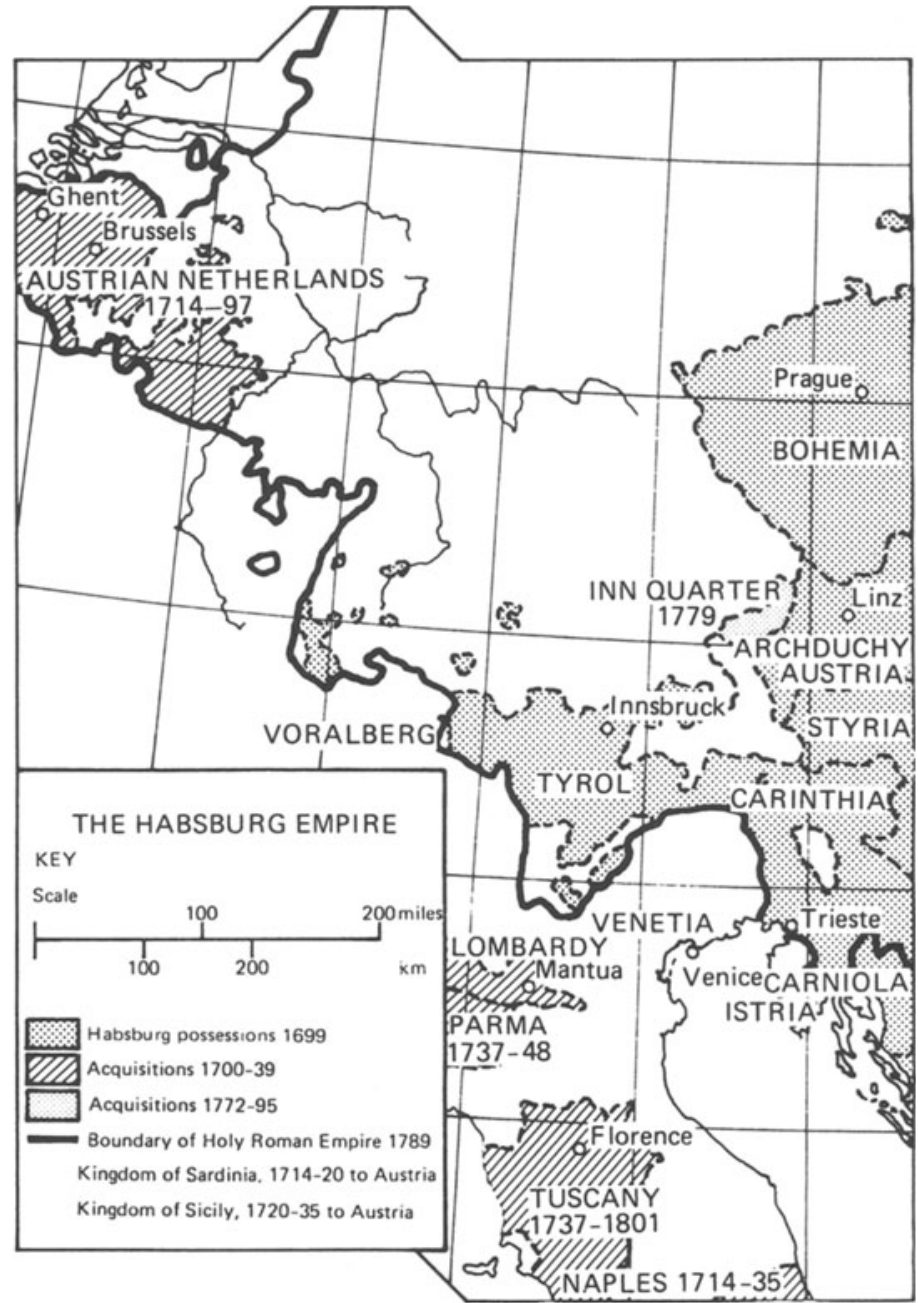

Map 2 The Habsburg Empire 
xxiii

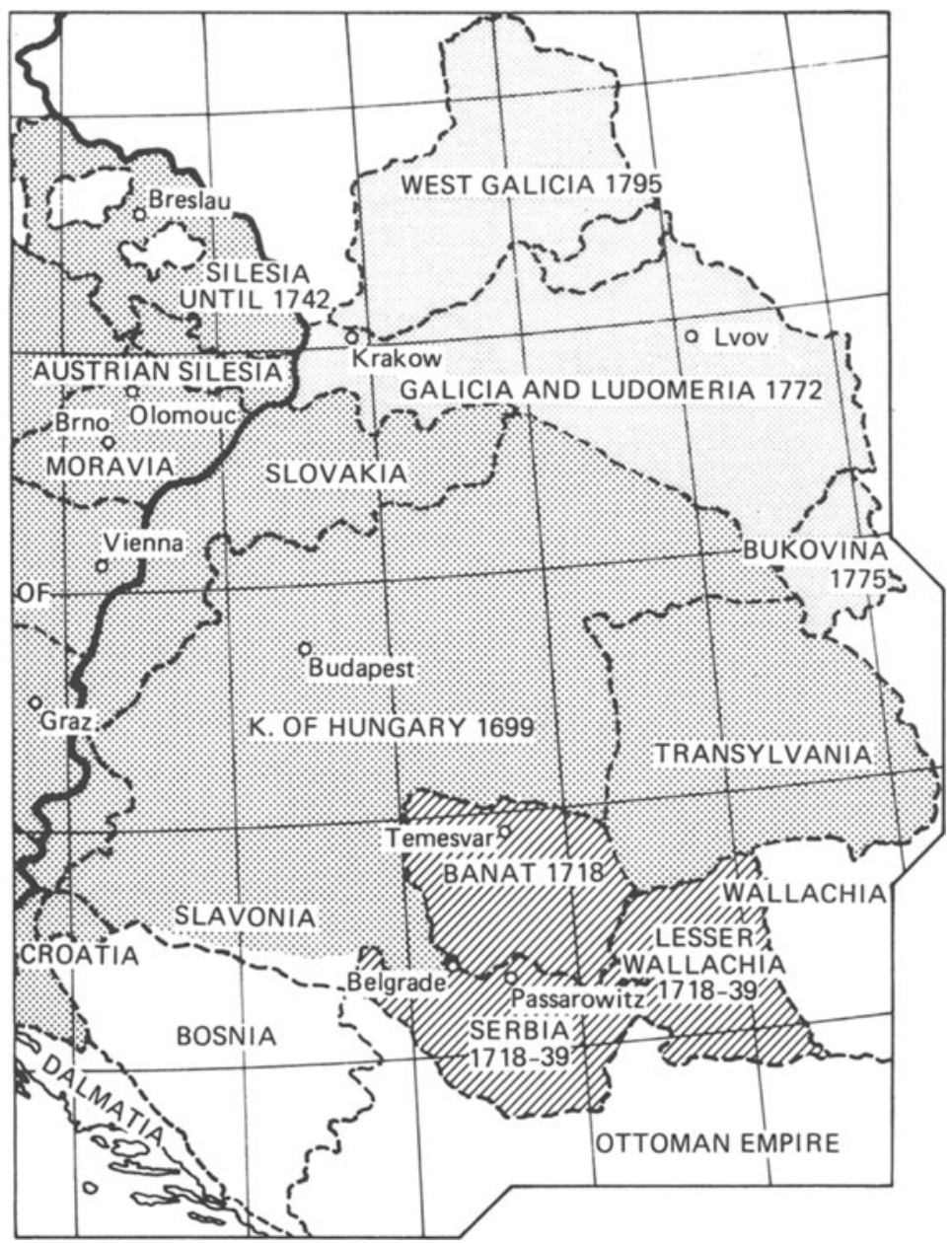


xxiv

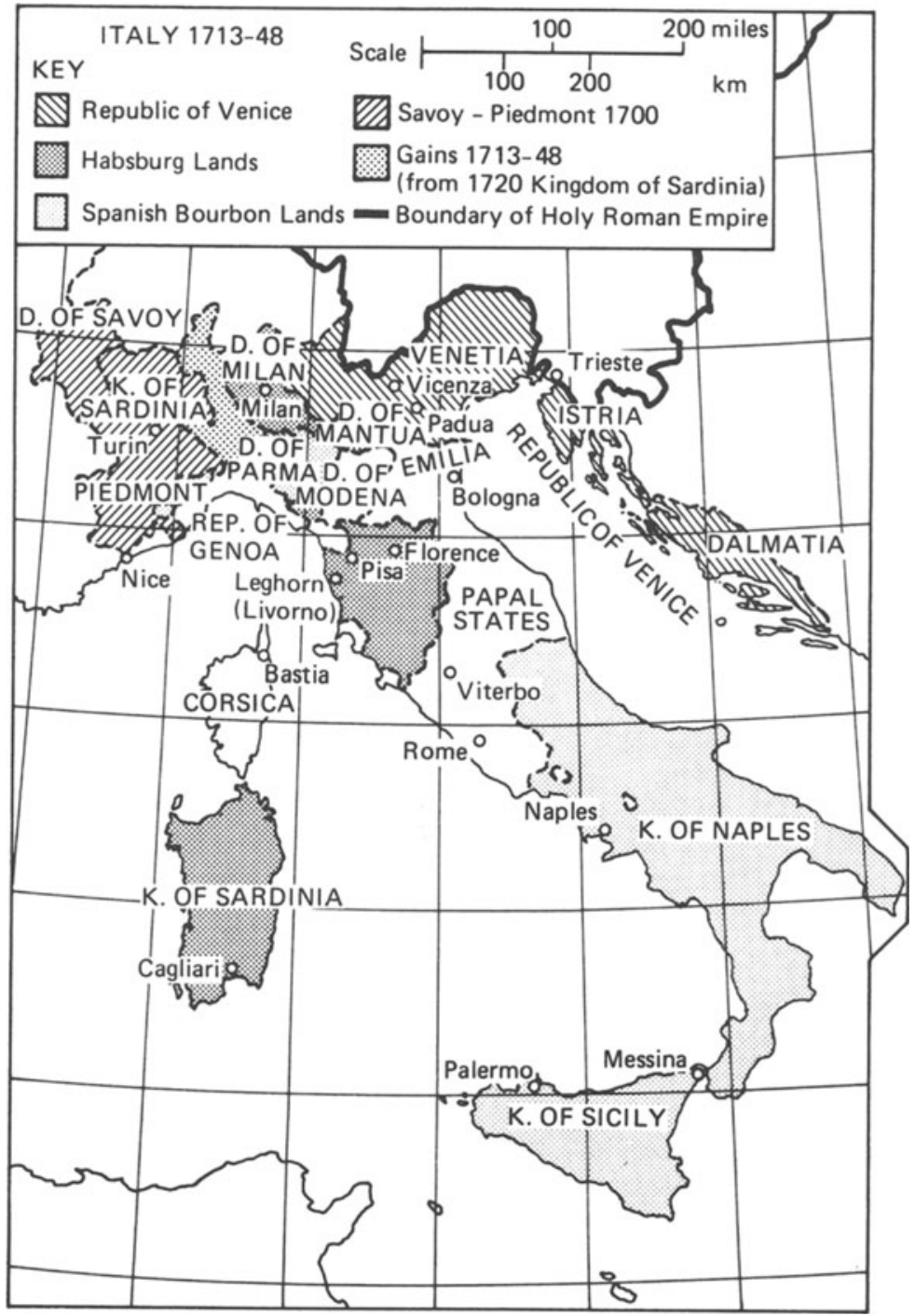

Map 3 Italy 1713-48 


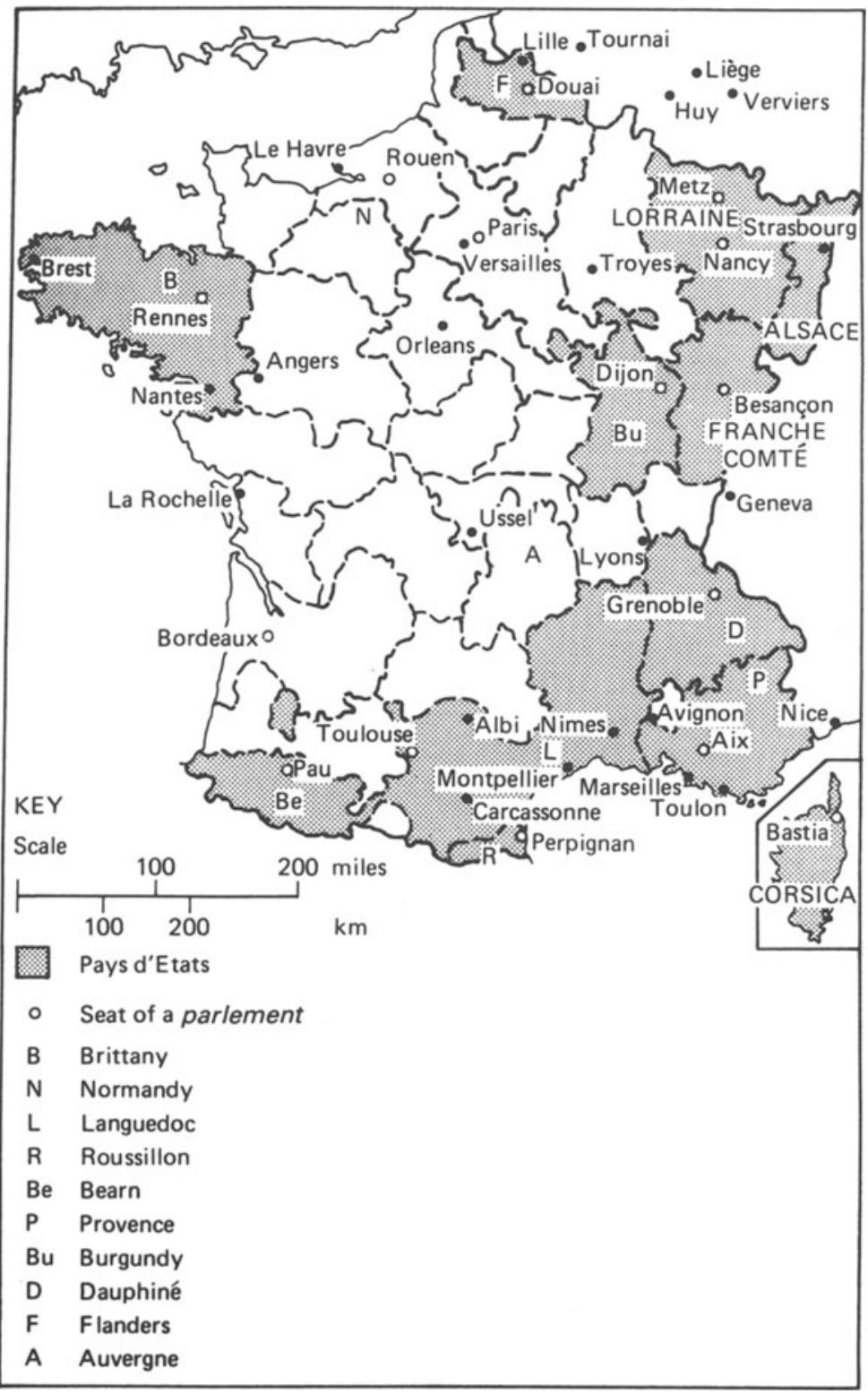

Map 4 France in 1789 